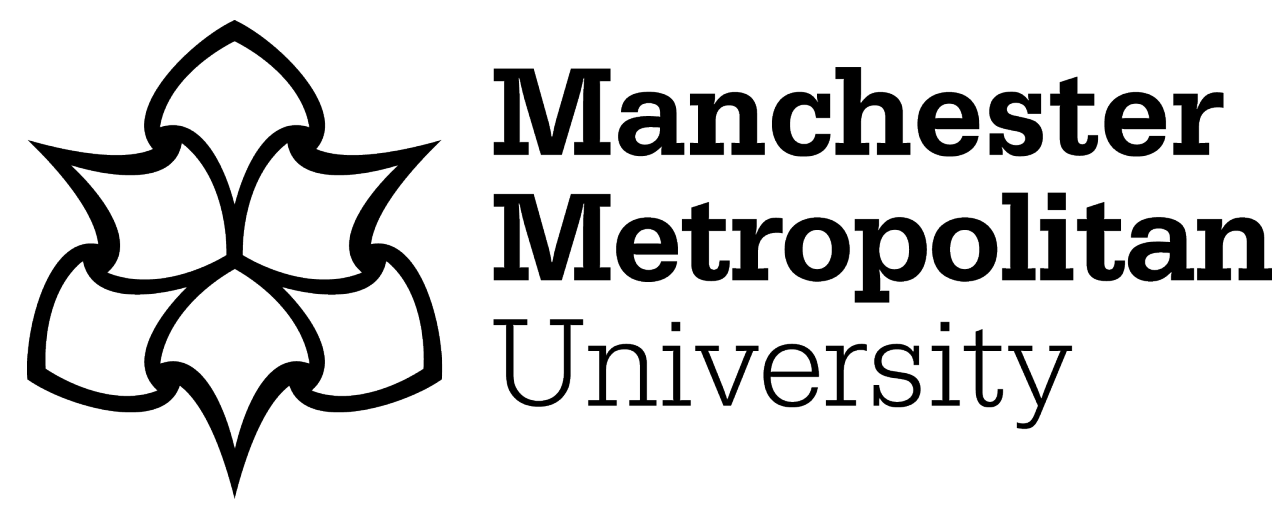

Finneran, N, Lichtenstein, R and Welch, C (2019) Place, Space and Memory in the Old Jewish East End of London: an Archaeological Biography of Sandys Row Synagogue, Spitalfields and its Wider Context. International Journal of Historical Archaeology, 23 (2). pp. 380-403. ISSN 1092-7697

Downloaded from: https://e-space.mmu.ac.uk/621360/

Version: Accepted Version

Publisher: Springer Nature

DOI: https://doi.org/10.1007/s10761-018-0474-1

Please cite the published version 


\section{Place, Space and Memory in the Old Jewish East End of London: an Archaeological Biography of Sandys Row Synagogue, Spitalfields and its Wider Context}

Nial AQ2 Finneran, 1 四

Email Niall.Finneran@winchester.ac.uk

Rachel Lichtenstein, 2

Email: R.Lichtenstein@mmu.ac.uk

AQ3

Christina Welch, 3

Email Christina.Welch@winchester.ac.uk

1 Department of Archaeology and Anthropology, University of

Winchester, Hampshire, UK

2 Department of English, Manchester Metropolitan

University, Manchester, UK

3 Department of Theology, Religious Studies and Philosophy, University of Winchester, Hampshire, UK

AQ1

\section{Abstract}

Sandys Row (London E1) is the only functioning Ashkenazi (Eastern European Jewish) Synagogue in Spitalfields and the oldest still functioning Ashkenazi synagogue in London. Located in an area, which from the mid-late nineteenth century until WWII was the centre of London's Jewish population, it is one of the last surviving witnesses to a once vibrant and dynamic heritage that has now virtually disappeared. This area has been the first port of call for refugees for centuries, starting with French Protestant Huguenots in the eighteenth century, then Jews fleeing economic hardship and pogroms in Eastern Europe in the nineteenth century followed by Bangladeshi Muslims in 
the twentieth century. Using a broadly archaeological analysis based very closely on the sort of practice widely used in church archaeology, the authors argue that much can be inferred about wider social and cultural patterns from a study of architectural space at Sandys Row and its associated material culture. This is the first such archaeological study undertaken of a synagogue in Britain and offers a new perspective on wider issues regarding the archaeological definition of religious practice and religious material culture.

\section{Keywords}

Buildings archaeology

Archaeology of Judaism

Post-medieval London

Place and memory

\section{Introduction}

"Spitalfields has been floated. It's delousing itself in readiness for a stock market quotation. One of nature's quislings, the area has always been ready to trim its cloth to the fashion of the moment.'

(Sinclair in Lichtenstein and Sinclair 2000: 6)

In 1968 BBC 2 Television broadcast a programme in a series called One Pair of Eyes featuring the Jewish singer Georgia Brown (1933-1992) and composer Lionel Bart (1930-1999). In the episode 'Who are the Cockneys now?' Brown and Bart revisited the London East End scenes of their Jewish childhood and found the area had changed. It was now becoming home to a new wave of immigrants from the Indian sub-continent. 1968 was a defining year for race relations in the UK; the year of the Conservative politician Enoch Powell's infamous 'Rivers of Blood' speech that railed against non-white immigration from the British Commonwealth (Whipple 2009). In 1968 the identity of the old Jewish East End (focused upon the districts of Whitechapel, Spitalfields and Stepney) in which Brown and Bart grew up was already diminishing, but in reality the East End of London always was an area of social flux (eg. Lichtenstein 2007; Marriot 2011; Palmer 2000). This was a heterotopic, liminal and transformative space on the eastern margins of the City, where successive generations of immigrants left material traces on the cityscape. As the writer Iain 
Sinclair notes above, Spitalfields now has taken on yet another identity, that of a gentrified and sanitized place.

Spitalfields has always been a place of layered identity. In the eighteenth century French Protestant Huguenot weavers, escaping persecution in their homeland, settled among the indigenous 'cockneys', and left a distinctive archaeological footprint evidenced by their handsome brick-built churches and houses, and distinctive domestic material culture (Parker 2009, 2011). Then in the nineteenth century large numbers of Ashkenazi eastern European Jewish immigrants arrived (Green 1991) and around the docks small Somali (El-Solh 2010), Chinese (Seed 2006) and West Indian (Banton 1955) communities developed, contributing to a cosmopolitan cultural mix contrasting heavily with what was still a very white, English capital (Kershen 2004 defines the neighborhood of Spitalfields as a microcosm, an area that reflects wider movements in social history, but this is a notion that we challenge later). Heavy bombing by the Luftwaffe in WWII left the area in ruins, the Jewish community left in droves, and after a period of abandonment the area re-invented itself again, as new migrants from Bangladesh and Pakistan began to arrive from the 1950s onwards. It was, and remains, an area with a heady and vibrant socio-cultural mix (see O'Neill 1999 for a personal and perceptive memoir), and a place that challenges the visitor to embrace shifts in place and identity (Kershen 2004, 2005; Mavrommatis 2010; Roemer 2009). No wonder, then, it has been celebrated in psychogeographic-orientated writings as a place of dystopic possibilities (eg Sinclair 2017), events (Ackroyd 1995) and quixotic individuals (Lichtenstein and Sinclair 2000).

The East End of London has thus always shown a capacity for reinvention, successive waves of settlers adding to the urban fabric (Nanzeen et al. 2016). This paper focuses upon a single archaeological site (a building) that bears witness to one of these episodes. In taking a conventional buildings archaeological approach, and utilizing techniques widely used in church archaeology and memorial recording in the UK, we seek to show how a small place of worship holds up a mirror to wider social developments in London from the nineteenth century onwards. In particular we pay attention to aspects of changing ritual space, patterns in memorialization and discarded material culture to gain a wider sense of the place of this synagogue within the wider social and cultural fabric of the old Jewish East End. This contribution seeks to move the archaeological study of Judaism on from rather fixed and traditional chronological and geographical perspectives (Hachlili 1998; 2001; for a British perspective see Hinton 2003; Isserlin 1996; Marks 2012 offers a survey closer to the material described here in terms of chronology), and to place it firmly within the context of historical/post-medieval archaeological studies and within the 
palimpsest of a complex urban setting (eg Hall 2006). Further, we show how community involvement within the project can inform strategies for heritage management and interpretation at the site within the context of the memory of the wider old Jewish East End (Kushner 1991).

$\mathrm{AQ} 4$

\section{Sandys Row Synagogue and its Place within the Socio-Cultural Fabric of the Jewish East End}

Sandys Row synagogue (Sandys Row, London E1; OS Grid Ref TQ3346381681) is located in a small maze of streets just to the east of Bishopsgate, north-east of the historic boundary of the City of London (Fig. 1). The building itself has a complex biography. It was originally built as a small place of worship for refugee French Huguenots in 1766 replacing an earlier building. After the Huguenots left in 1786, it was taken over by Universalist Baptists from 1792 to 1824 when it was briefly used by the South Place Ethical Society (a secular group) and then by a Scottish Baptist congregation (Stell 2002: 177) when it was known as Parliament Court Chapel. In the 1840s a small community of Dutch Ashkenazi Jews from Amsterdam, who had come to London primarily as economic migrants, settled in West Spitalfields. It is important to note however that these nineteenth century Jewish population increments echoed earlier and extensive medieval Jewish settlement in London, a picture also being revealed by archaeological research (Hinton 2003; Isserlin 1996). After initially renting various buildings in the area they eventually converted the building to their own use. There is an important social context to the development of the Synagogue, however. When invited to take the seats reserved for the poor in the nearby larger, long-established Ashkenazi synagogues, the Dutch community refused to do this as they wished to worship in their own unique style. This decision caused a rift within the Ashkenazi community to such an extent that when the Sandys Row synagogue was finally consecrated in 1870, the Chief Rabbi of the Ashkenazi community refused to conduct the service and (very unusually) the haham (Sephardic term for the Chief Rabbi) of the Sephardi community from nearby Bevis Marks synagogue (Bevis Marks, London EC3; OS Grid Ref TQ33398125) performed the rite instead (sandysrow.org 2017).

\section{Fig. 1}

Location of Sandys row synagogue in East London 

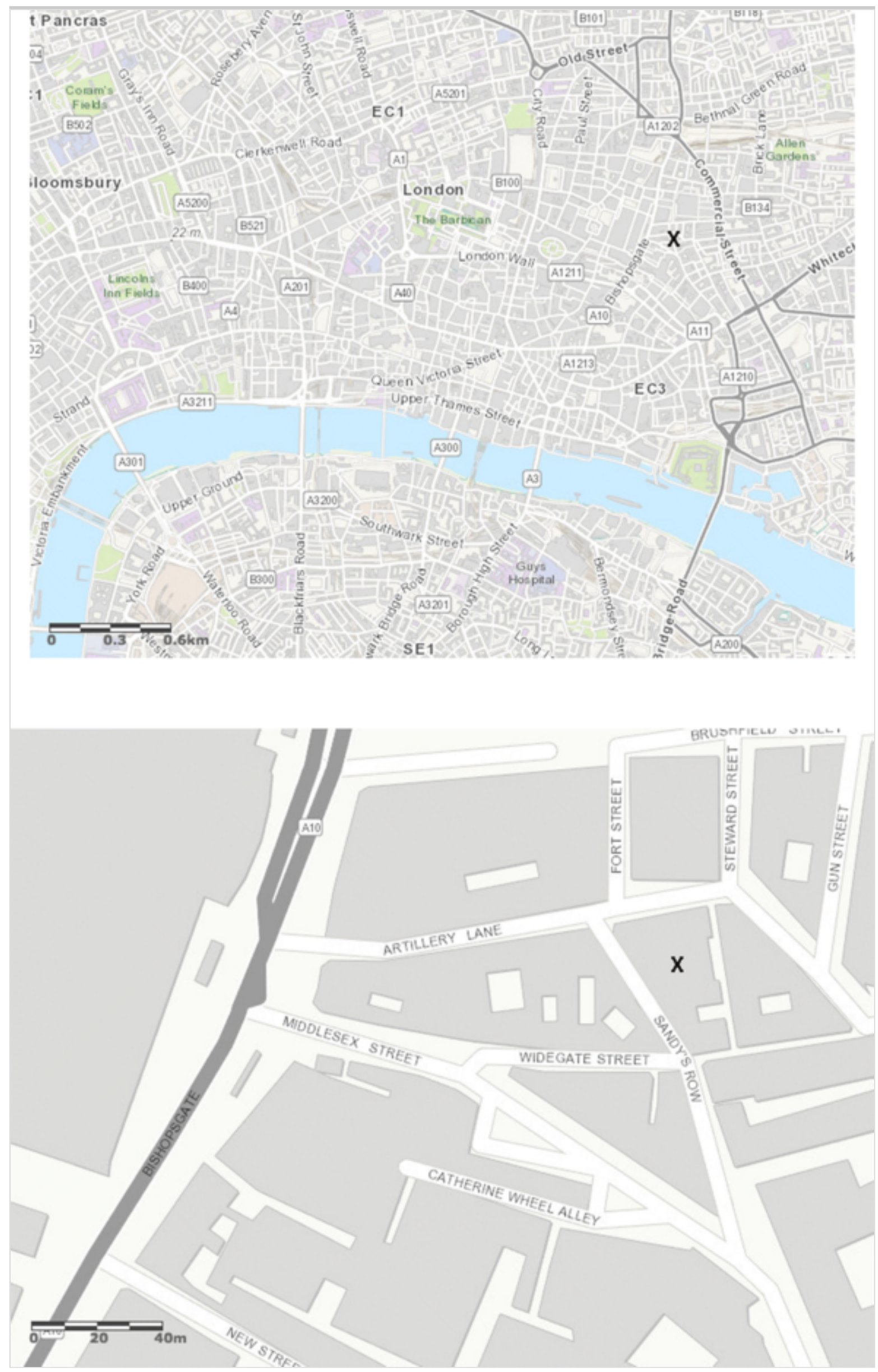
This Dutch Ashkenazi community was a highly demarcated and distinctive one, focusing predominately upon cigar manufacture, cap making and diamond cutting amongst other trades (Kadish 2006: 10-11). They became known by their fellow Ashkenazi neighbours as 'chuts' which was a term applied to Jews who migrated from Holland in the nineteenth century by their Jewish neighbours from other places such as Russia, Germany and Eastern Europe. It is believed to be a derogatory label, which may derive from the Hebrew word for 'outside' (Brotmanblog 2014; Jacobus 1998). In 1854 they formed a friendly society (hebra) called the Hevrat Menahem Avalim Hesed v'Emeth (Society for Comfort for the Mourners, Kindness and Truth) which was originally established as a burial society, but eventually became a fund for raising monies to purchase the building. The noted synagogue architect Nathan Solomon Joseph (1832-1909), who had also designed the Central Synagogue in Great Portland Street in 1869 (Hallam St, London W1; OS Grid Ref TQ28928181) and who was an ardent defender of the smaller synagogues' independence against their larger city neighbours (Jamilly 1955), remodeled the chapel along the lines of the nearby Great Synagogue in Dukes Place, London EC3 (destroyed in a German air raid in 1941; OS Grid Ref TQ 33448119).

Despite being designed by such a noted architect as Joseph, Sandys Row has always been considered the synagogue of the 'poorer brethen', as it was described in an account in the Jewish Chronicle during its inception in 1870 . The congregation wanted a building they would be comfortable in and the size, architecture and simplicity of the 'humble little synagogue in Sandys Row' reflects this need. The reporter from the Jewish Chronicle, in an article dated 11 th November 1870 (page 8), stated the synagogue had been 'reared by the hardly-earned gains of the working man' located in a 'squalid street in Spitalfields.' 'Little was spent on decoration' as it was not desired, unlike the ornamentation of the Great Synagogue in Dukes Place, which was deliberately ostentatious to reflect the wealth of the congregants, as was Bevis Marks and the Great Machkzike Hadass Synagogue (now the Brick Lane Mosque, Brick Lane London E1; OS Grid Ref TQ 3385581814). Sandys Row was thus intentionally simple and plain to reflect the desires and needs of the pious, poor Dutch community who worshipped there. In this way the building has become a unique example of working class synagogue architecture in the area, most of which was not purpose built and has since been demolished.

The synagogue was briefly (1887-1899) the largest of the Jewish congregations forming the Federation of Synagogues. From 1899 there was an agreement with the United Synagogue for burial rights and in 1923 the congregation joined the 
United Synagogue as an Associate Synagogue and acquired the freehold of the property. By 1949 it was independent, although associated for burial purposes with the West End Great Synagogue, Dean Street, London W1 (sandysrow.org 2017). The synagogue also acted as the centre for the Secretariat of the Stepney and Whitechapel Traders Association, and the basement used for storage. Nearby Petticoat Lane market was very much regarded as being 'the great Jewish market' and was originally a centre for itinerant Jewish rag trade pedlars (Vaughan 1994: 17). The synagogue remains in use by the Orthodox community to this day, although the focus of Jewish settlement in London as a whole has shifted towards North London in suburbs such as Stamford Hill, and further out in Barnet and Elstree, as well as further East to places such as Redbridge, Ilford and Southend, part of a wider phenomenon of drift and socio-cultural integration (Newman 1985; Waterman and Kosmin 1986). Daily afternoon services (mincah) still take place in the building and a small congregation gathers for services every other Shabbat and on high holy days, but it is a far cry from its high water mark in the late 19th-mid twentieth century when it served a central religious and social role to a thriving local Jewish community of Dutch origin, and became one of the most distinctive of the capital's Ashkenazi synagogues.

Having considered the history of the building itself, let us now turn to its wider context within the urban landscape of the Old Jewish East End. Memory sites of the old Jewish cultural heritage of this part of East London are diverse and not limited solely to synagogues, although they are the most visible components. Synagogues are central elements of Jewish life, and serve at once as ritual buildings as well as having a strong community focus. They formed crucial nodal points in the rhythms of everyday life of the urban fabric of the old Jewish East End (Vaughan et al. 2016), and nor are they of a uniform spatial design, reflecting different social and economic conditions of the worshippers within them (Glasman 1987). They also embody gendered space, as they are predominantly male ritual spaces where women are only permitted to worship in certain parts of the building. This is an important issue to which we shall return. As we shall see below there are very distinctive unifying architectural elements that inform the use of space within an orthodox synagogue building, but (and it is important to note this in the context of the current case study) they do not have to be purpose-built dedicated buildings. There are a number of interesting examples of historic synagogues within the immediate area of Spitalfields, which emphasize this idea of fluidity of ritual space (Nanzeen et al. 2016; Kershen and Vaughan 2013).

The present Jamme Masjid (mosque) on Fournier Street/Brick Lane E1 (OS Grid Ref TQ 3385581814) was converted from a Jewish synagogue (the Spitalfields 
Great Synagogue, or Machzike Hadath) in 1976, which in turn, like Sandys Row, had been originally erected in 1743 as a Huguenot Chapel (Alexander 2011; Stell 2002: 116-17). Externally there are few material traces of this conversion process, apart from changes in signage, the addition of female only entrances and a tall free-standing tubular steel minaret. The main adaptations are more evidenced internally, with the creation of a wide haram, or prayer room with a mihrab (semi-circular niche indicating the direction of Mecca and thus the direction for prayer), rather than a ritual space crowded with seats. The ritual orientation of the building has therefore shifted, away from the east to the qibla (direction of Mecca), roughly a south-eastern direction (Fig. 2).

\section{Fig. 2}

Sandys row synagogue: main entrance 


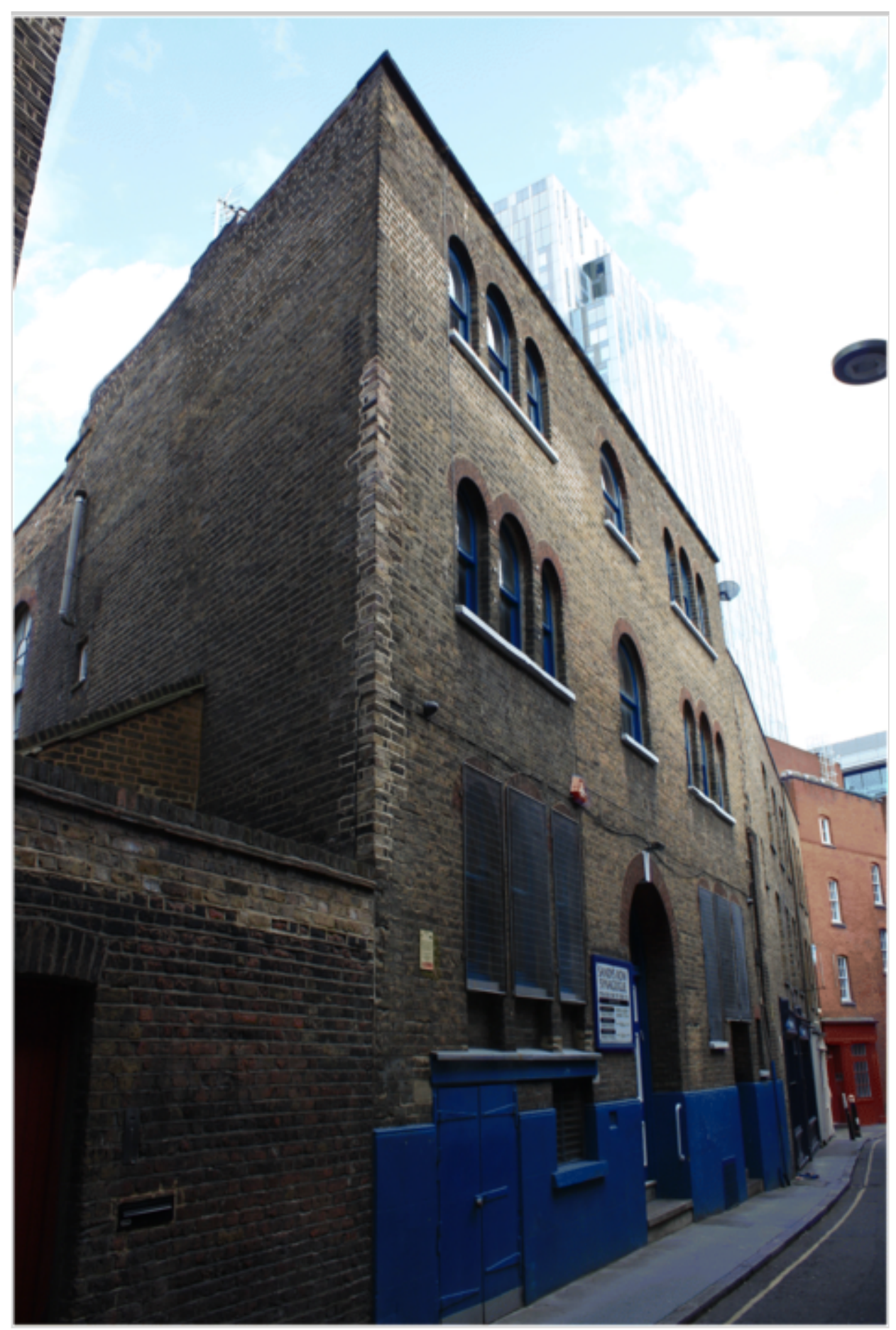

AQ5

The synagogue at 19 Princelet Street (London E1; OS Grid Ref TQ33908185) offers another contrast in the development of ritual space. The synagogue, which was founded in c 1862 and in use until the 1960s was built over the back garden of an eighteenth-century Huguenot silk weaver's house. Internally the building, which is owned by the Spitalfields Trust, is in a bad state of repair. Much of the plasterwork internally is in a poor condition. There are plans for the site to be opened to the public as a Museum of Immigration (reflecting the wider history of the area) when the building's restoration is complete (date unknown). The site is also well known as the dwelling place of the polymathic autodidactic central 
character of Rachel Lichtenstein's eponymous book, Rodinsky's Room (Lichtenstein and Sinclair 2000).

Bevis Marks (Bevis Marks, London EC3; OS Grid Ref TQ33398125) is not part of the Ashkenazi Jewish heritage canon, and arguably sited towards the northern boundary of the City of London, is not part of the East End Jewish landscape per se but needs to be mentioned here for the sake of completeness of analysis, as it is the oldest synagogue surviving in England. Located some $500 \mathrm{~m}$ to the south of Sandys Row in the northeastern corner of the City, the building dates from 1701. Designed by Joseph Avis, architecturally the exterior 'shares features with ...nonconformist meeting Houses' (Kadish 2006: 4) but its interior is based upon the design of the Great Synagogue of the Sephardi community in Amsterdam, its mother community. A brick-built rectangular building, the synagogue is sited within a court as Jews were prohibited from building on public roads. In terms of scale and monumentality, Bevis Marks operates on a different plane to the surviving Ashkenazi synagogues beyond the City boundary, evidencing a long mercantile-orientated settlement of the older established Sephardi communities (Kadish 2004; Rubens 2001), although the old Great Ashkenazi Synagogue on Dukes Place, destroyed in a 1941 German air raid, certainly rivaled it in terms of scale (Roth 1950).

In addition to the synagogues, either in use, deconsecrated or converted to another ritual use, other buildings contributed the socio-cultural fabric of the Jewish East End. The nearby Jews Free School (located in nearby Bell Lane Spitalfields, London E1) was functional from 1822 until it was destroyed in 1945 during the Blitz. It was established to provide education for the sizeable Jewish community living in the area with a primary aim of Anglicizing its Jewish pupils by improving English language proficiency among the new arrivals; Yiddish was not allowed to be spoken in the school (Kadish 2006: 15). On Brune Street (London E1) is a former Jewish soup kitchen (Kadish 2006: 11); this evidences a wider system of intra-community mutual social support. Jewish business names also remain on the sites of some shops, (for example, the C H Katz shopfront on 92 Brick Lane, London E1, a former paper bag seller, now a gallery; Lichtenstein and Sinclair 2000: $51 \mathrm{ff}$.) In addition it is also pertinent here to mention a large number of late-nineteenth century wall memorials in the narthex of Christ Church at Spitalfields (Commercial St, London E1; OS Grid Ref: TQ33748178). These are of course Christian dedications, but the nature of the names and extensive use of Hebrew attest to a slightly different emphasis than would normally be expected. These are memorials to individuals who either converted to Christianity from Judaism or to Christian missionaries instrumental in the process of conversion (Smith 1981). The form of language used on the 
memorials is very distinctive in this regard, and such artefacts furnish material evidence of the politics and poetics of the conversion process (Fig. 3).

Fig. 3

Memorial stone to the Reverend Aaron Stern, Narthex, Christchurch, Spitalfields

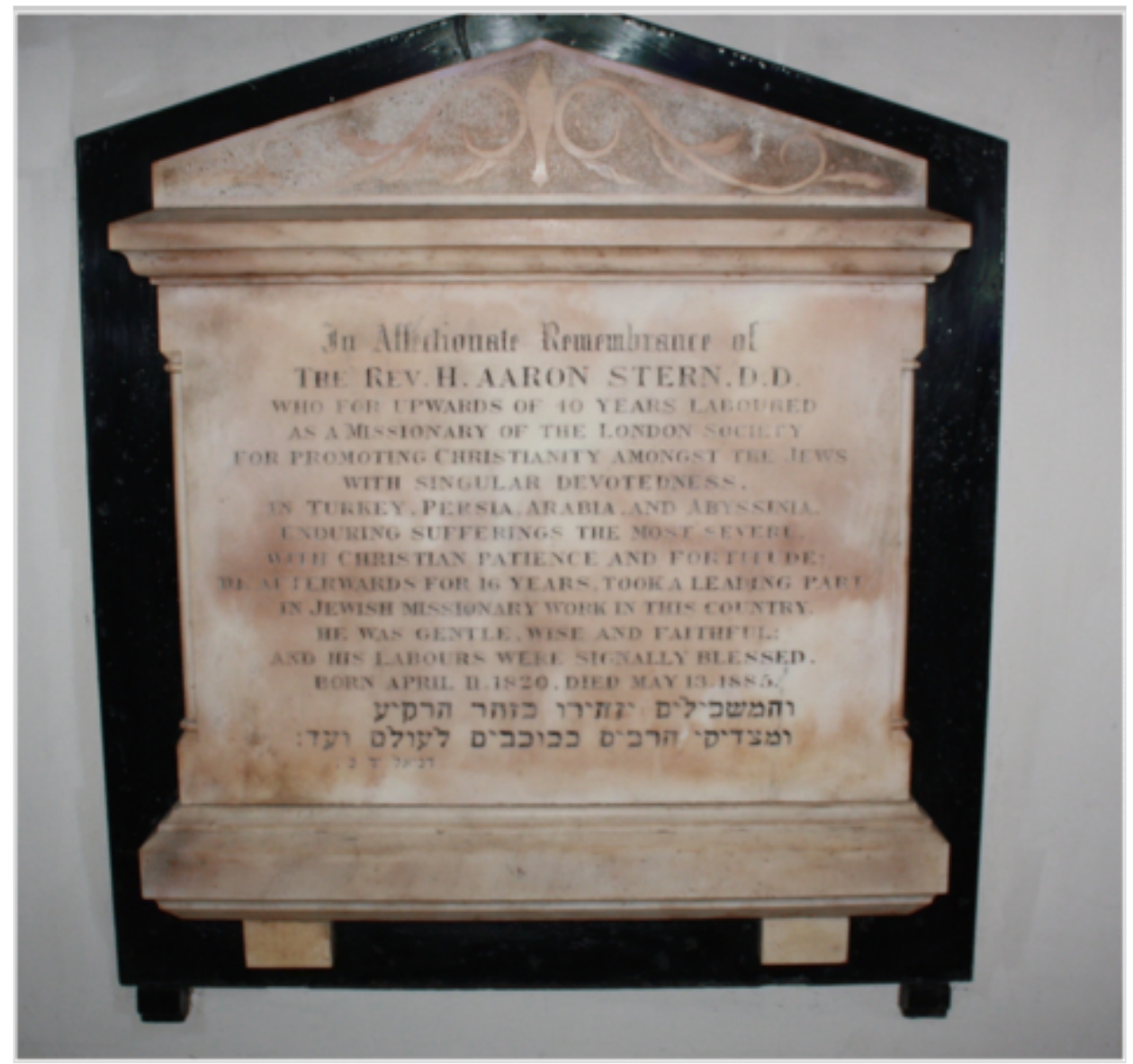

The foregoing section has delineated the context of Sandys Row Synagogue itself as part of a wider Jewish East End urban landscape, and one, in fact that is rapidly disappearing (Kadish 1991). The notion of an urban palimpsest (Hall 2006) is a suitable metaphor for these layerings of history, and in this paper we argue that the synagogue building itself represents a microcosm of such a sociocultural palimpsest, and that by approaching the structure using archaeological methodologies, we can understand how the organization of the structure as well as its associated material culture holds up a mirror to the vibrant social history of the old Jewish East End. The project described herein primarily arose as a collaborative project between author and historian Rachel Lichtenstein and archaeologists and heritage specialists from the University of Winchester (Niall Finneran and Christina Welch).

For some years now, an outline plan has been in place to convert the basement of the Sandys Row synagogue into a heritage centre focusing on the history of the 
old Jewish East End. Already one of the authors (RL) has conducted an extensive programme of oral history research among former Jewish residents, and this is feeding into plans for an interpretation centre for the site. As a consequence of this potential development, a small-scale buildings archaeology survey was initiated and an inventory of the contents of the basement was undertaken in May 2016. During the course of this work however (which was conducted with the full support of the Synagogue community), it became apparent that the activity of recording 'rubbish' was yielding some potentially important archaeological ideas and results. Very quickly a material biography of the synagogue emerged through a study of old maps, plans, memorials and discarded material in the basement. The act of clearing the basement as well as the recording of the interior memorials led us into new interpretations of the building as more than just a place of worship, rather a repository of memory.

In the following section, three key categories of archaeological/material evidence are examined. Firstly the fabric of the building itself, mapping structural changes visible through buildings archaeology analysis against old maps, plans and historical documents to enable us to chart the ritual re-orientation of the building (cf Hicks and Horning 2006). Secondly we consider the placement and typology of the commemorative material culture within the building, a category of evidence that explicitly ties the synagogue as a building to the notion of personhood, death and lineage in the cityscape beyond (cf Mytum 2006). Finally, we consider the nature of the pattern of discard of material culture within the basement of the building and how this might relate to the social lives of the peoples attached to this building.

\section{Changing Ritual Space: A Buildings Archaeology Biography}

Before we discuss the historical and archaeological analysis of the building itself, it would be useful to look at the present building as an example of Jewish ritual and social space, and to understand the meaning and interplay of the different elements. The brick-built synagogue is entered from the west through a double door just above street level; a sign clarifies the meaning of the building: over the door, painted onto a window is a Star of David and to the right hand side of the door frame is a mezuzah (a piece of parchment (klaf) with hand-lettered verses from the Torah (Deut 6:4-6,9) secured within a decorated case).

Upon entering the building, stairs lead down into the basement (currently in use as a storeroom) and a male toilet. The basement is also used as a location for the geniza, the store room or repository for the worn holy scrolls (Sefer Torah which 
have become pasul/unusable, Hebrew language books and papers on religious topics that may contain the name of G-d) prior to their disposal by ceremonial burial. This is a small free-standing brick structure built into the southwest corner of the basement (see Fig. 4). Stairs lead up from the entrance way to a first floor vestry on the left, which contains the safe where the Judaica (i.e. synagogue regalia) is kept. A door leads ahead into the synagogue itself. The main body of the synagogue is panelled with pine panels of wood; upstairs is a gallery with lines of pews, which is reserved for women, girls, and boys yet to be Bar Mitzvah'd, as is normative in the Orthodox tradition of Judaism. Below, the raised bimah structure (a podium from where the Torah is read during services) occupies the centre of the room. The room is flanked by lines of pews for male congregants; unlike a church these do not face forward but face the bimah as that is where Sefer Torah (the hand-lettered parchment Torah Scroll/s contained in the synagogue Ark) is read from during a service, it is the ritual focus of the building, although the most Holy place is the Ark (hekhal, 'Holy Place'), at the east end.

\section{Fig. 4}

Floor plan of Sandys Row synagogue. Key: A, Ark; B, Bimah; C, original western entrance stairs of the chapel (surveyed by N. Finneran)
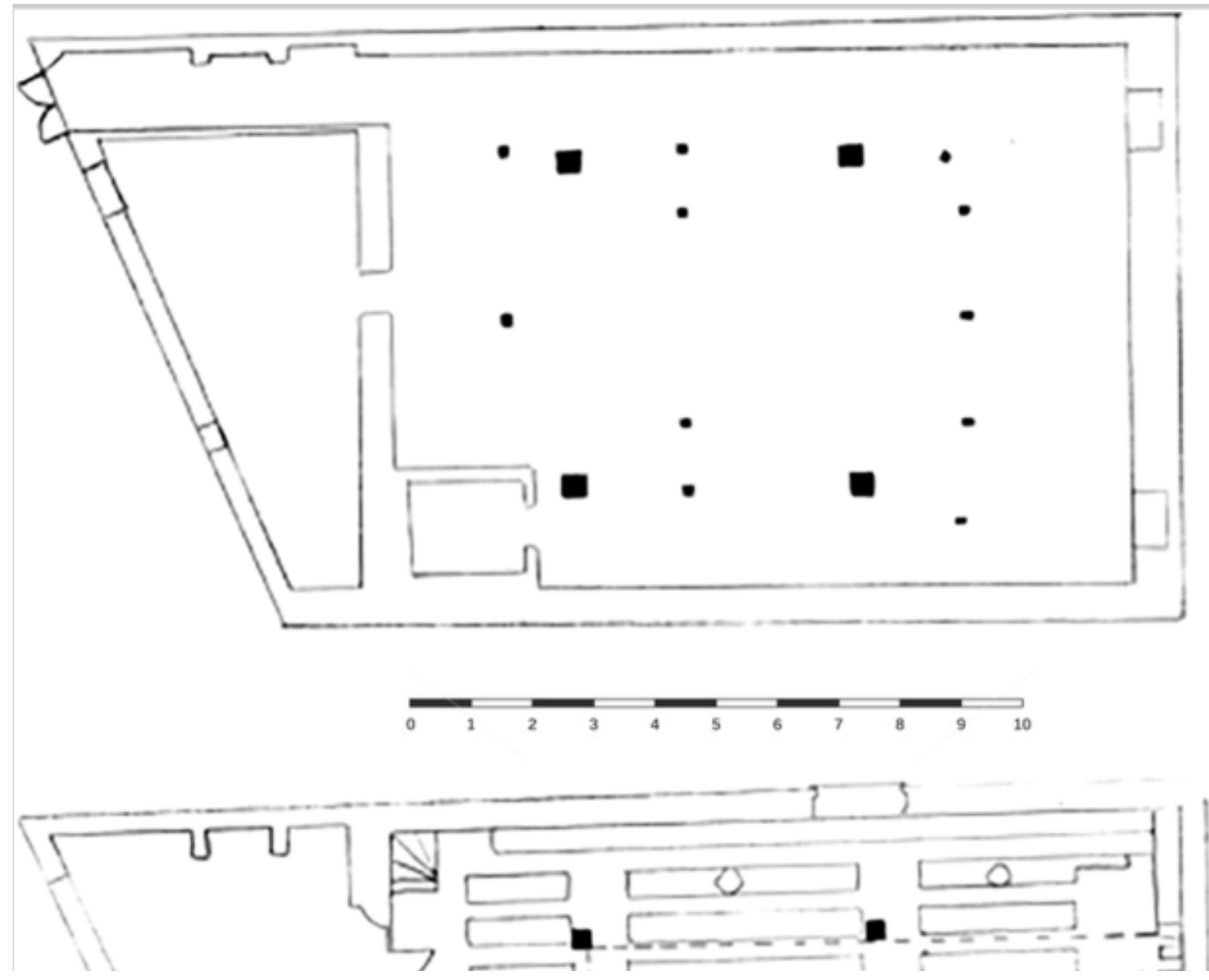

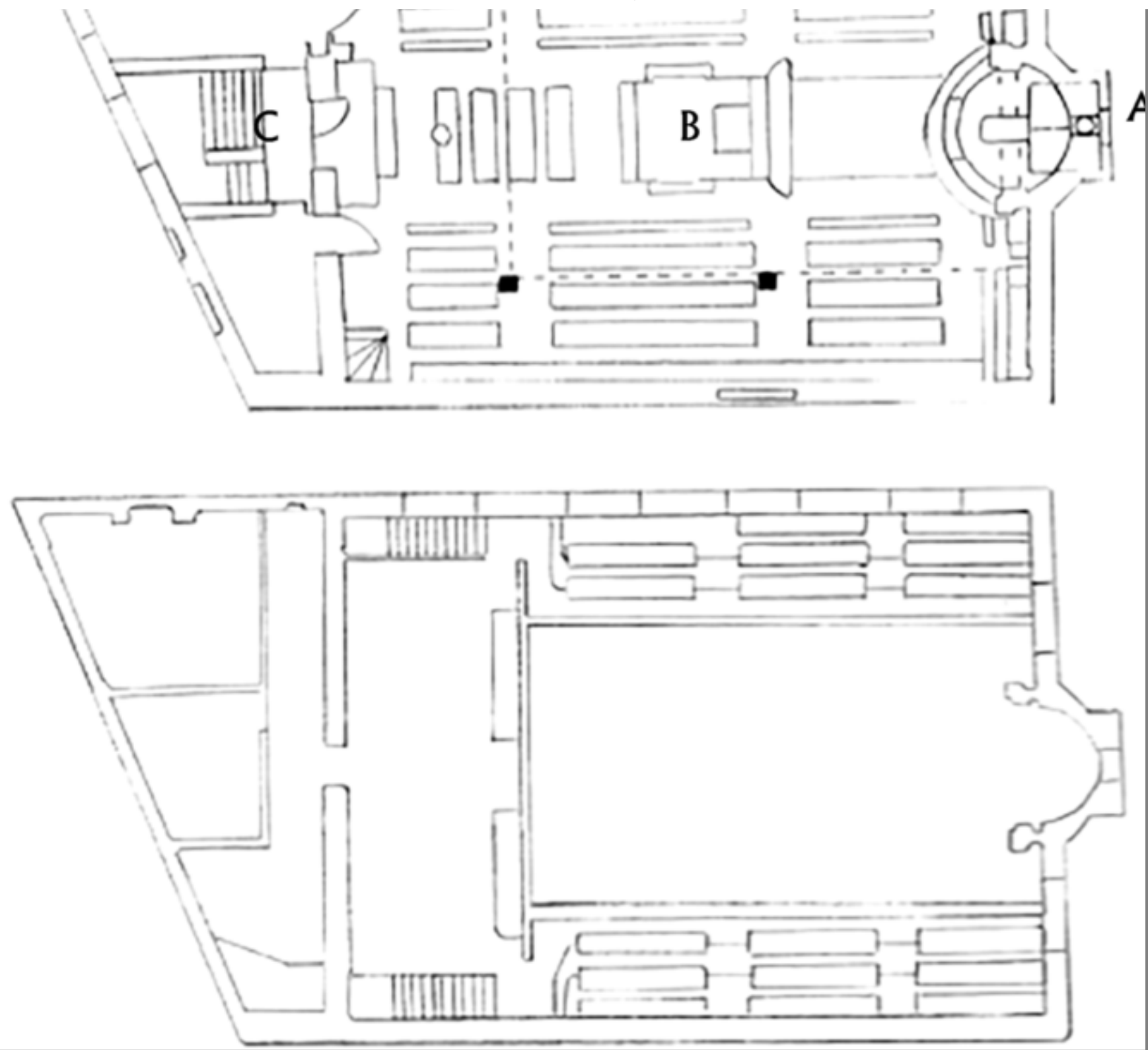

The remainder of the space above at the west front is taken up with a kosher kitchen, a female toilet and on the top floor a flat which is currently undergoing refurbishment. With a limited congregation, it is difficult to maintain the upkeep of what is a grade II listed building. Extra income and revenue streams are always being sought, and as such the synagogue has become a multi-use structure. The basement conversion into a heritage centre is part of this process, as is the renovation of the old caretaker's flat to provide a rental income. In order to understand the developmental history of the building, we started by consulting old maps and plans of the structure. In addition the team undertook detailed internal survey and measurement of the building fabric. Combining these approaches, the following biography of the building emerges.

The first building indicated on the site is clearly seen on John Rocque's 1746 map of the area (Fig. 5 top), and it is indicated as 'French Church', clearly referring to a Huguenot chapel (prior to this map, the area is shown as open 
fields). What is interesting is that the building indicated on this map is not on the alignment of the current building; rather than sitting within the current footprint, the map appears to show a longer and thinner structure aligned on a north-south axis along Parliament Court. This is an odd orientation given that the emphasis of a church is usually on the east-west longitudinal axis. This may reflect French tradition translated into the refugee cultural context, where the Huguenot 'temples' (as they were termed) of sixteenth and seventeenth century France deemphasised the focus upon a single ritual point, such as an altar, and emphasized communality of worship (in fact along the same lines as a Quaker meeting house; Spicer 2002).

\section{Fig. 5}

Map regression evidence for the development of Sandys row. Top: segment from John Rocque's 1746 map (source: Bishopsgate Institute, London). Middle: segment from Richard Horwood's 1792 map (source: Bishopsgate Institute, London). Bottom: segment from c. 1870 1: 1056 Town Plan (source: tiles: lond-0100700056$1 \mathrm{http}: / /$ digimap.edina.ac.uk downloaded 2017-11-02)

\section{AQ6}
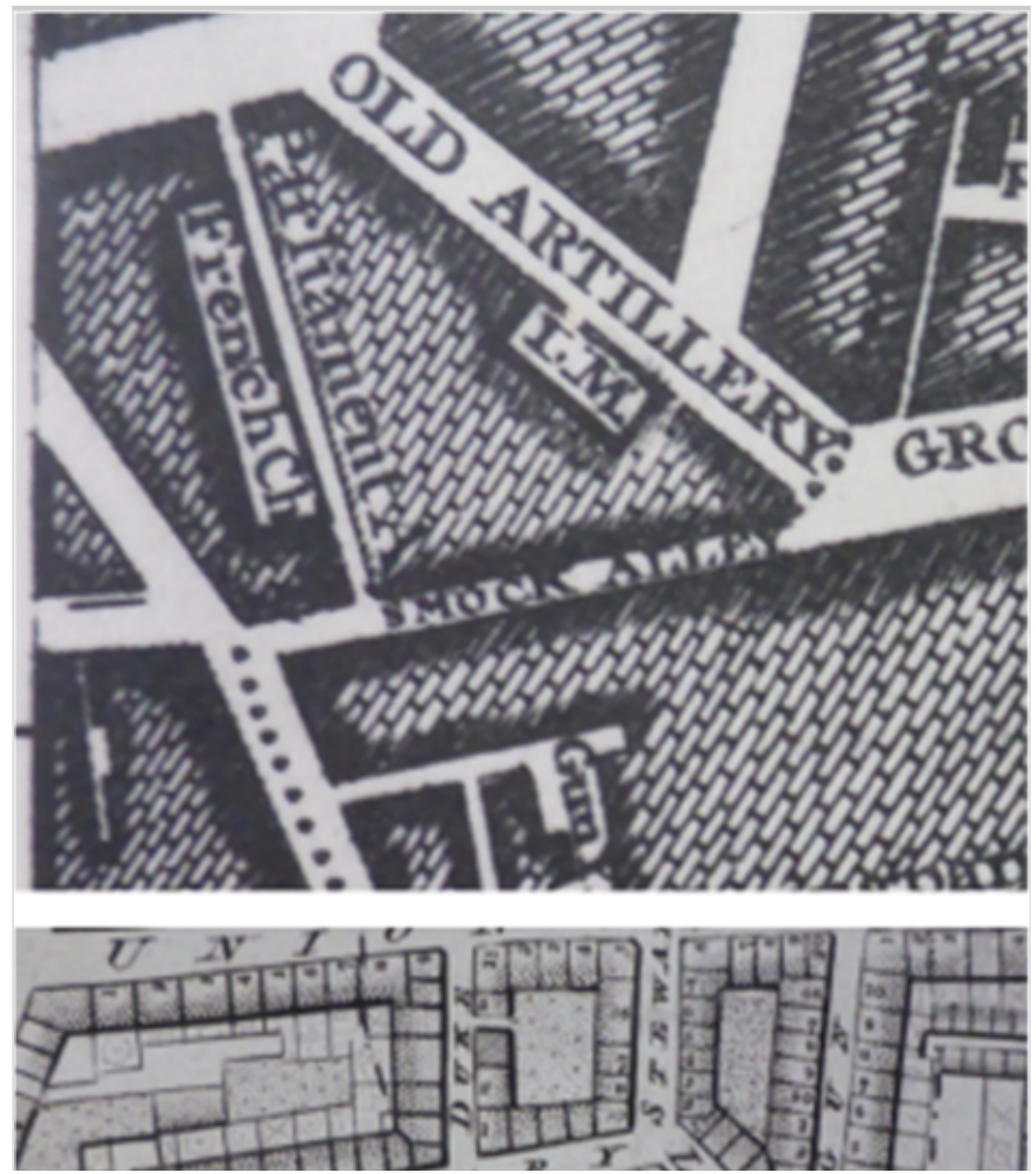

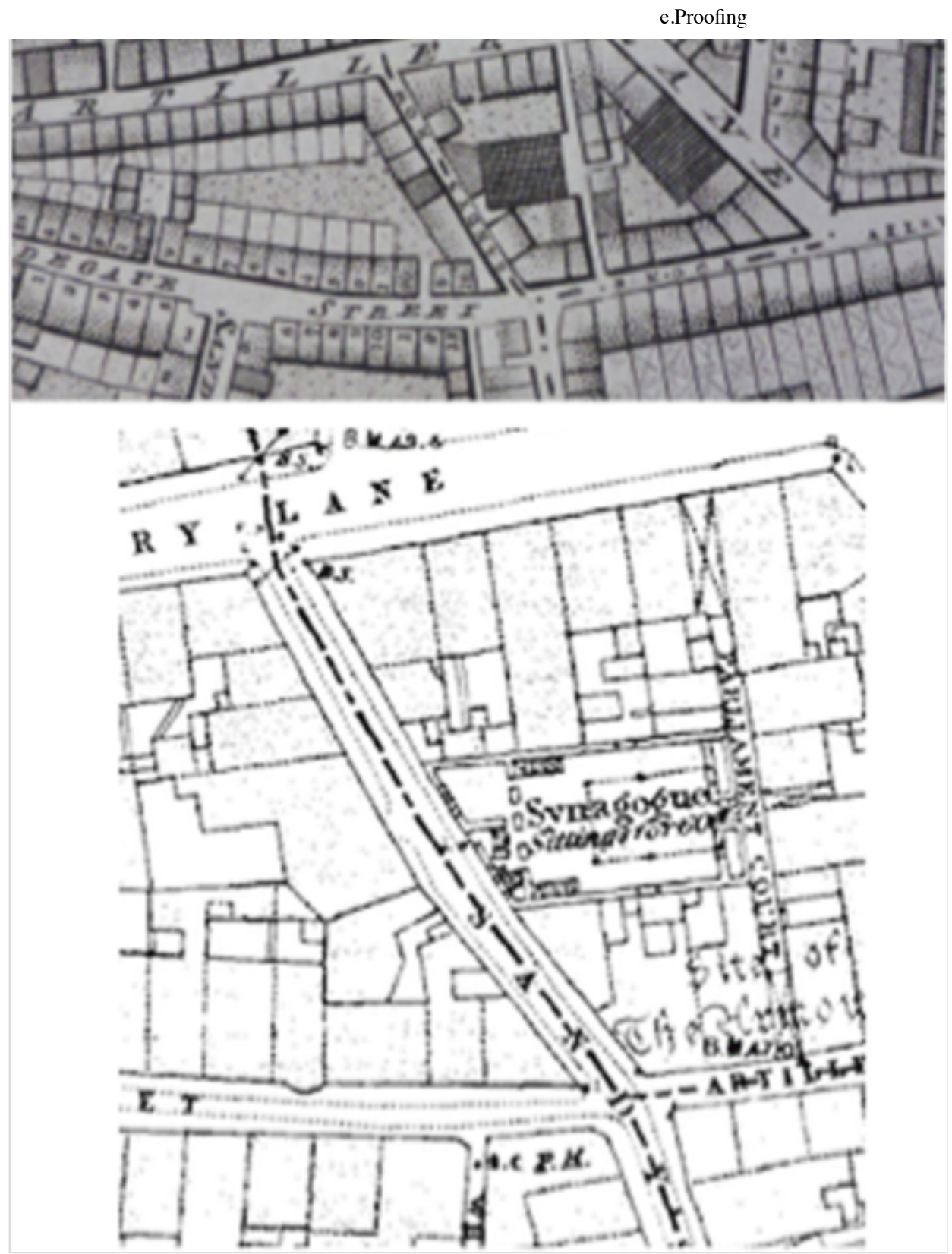

By the time of the drawing up of Horwood's 1792 map (Fig. 5 middle) the building is shown as sitting within its current footprint (phase two), during which time it had passed from Huguenot use to varied Baptist groups, and appears on this evidence to have been enlarged somewhat, roughly occupying its present footprint (Kadish 2006: 10). The older possibly wooden structure had been demolished by that time and the 1766 brick chapel had been erected on the site. The conversion of this chapel into a synagogue is evidenced in the first edition of the OS 1:1056 Town Plan (1870 iteration) (Fig. 5 below), where the building is indicated as 'Synagogue sitting (sic) as 60'. The building depicted on this map shows that several structural changes have taken place over the last century. For some reason, the map appears to show internal details, displaying clearly the added western range enclosing the flight of steps that afford entry to the ritual space from the porch. The east end of the building is shown on this map as being perfectly straight along the alignment of Parliament Court. 
An account of the consecration ceremony presented in the Jewish Chronicle dated 11th November 1870 (page 8) broadly supports the cartographic evidence, but raises some additional queries regarding the orientation of sacred buildings. The Jewish Chronicle account notes that the former chapel structure was entered via Parliament Court through a 'miserably contracted entrance' which since the chapel's redevelopment into a synagogue in 1870 had a purpose built vestibule range on Sandys Row at the west. Further, the text notes the staircase to the 'ladies gallery' as well as a 'ladies retiring room', implying that gendered segregation within the ritual space was practiced from the start, which would be the norm for an orthodox synagogue both now and then. The account notes that no women were present at the start of the consecration ceremony, only entering after the first speeches. The Ark is described as being at the north-west end of the earlier building, and the entrance in the south-east. This was because the original entrance to the Parliament Court Chapel was in Parliament Court, when the Jewish community first rented the building they could not afford to make the necessary changes to orientate the ark facing east. The Jewish Chronicle article states they had rented the building for approximately 5 years before the conversion and used it as a makeshift house of prayer, however as orthodox Jews they would have prayed facing east wherever the ark was situated. This is seen in many buildings which are not purpose built but used by orthodox Jewish communities as places of worship, wherever Jews are placed around the world they will pray facing east.

Over the years, the interior has changed from that described in the 1870 account. A light-coloured thin wooden panelling was installed over all internal walls and the wrought iron screens of the bimah in the 1950s. The pillars were covered with a marbled plastic effect, and electric rather than candlelight became the norm. This was a relatively cheap solution to help neaten the interior of a building as was by this time becoming only marginally utilized. We were able under supervision to remove a section of paneling to reveal an earlier (probable nineteenth century) wallpaper covering on top of degraded plaster skim directly upon brickwork. The large windows in the western range of the original church building are fossilized as doorways on the upper level, and partly blocked with plaster board. Post-War austerity would have played a part in the choice of material for internal decoration, and it offered (superficially at least) the impression of more expensive internal paneling and marble. But the effect is only superficial, it is almost as if the community had standards to maintain, but were unable economically to do so. Having discussed the changing ritual space as evidenced by archaeological, cartographic and textual analysis, we now turn to 
another important element of material culture within the synagogue: the archaeology of commemoration.

\section{Memory Made Material}

Commemoration of individuals and events within the human lifecycle are important elements of religious behaviour. Archaeologists in particular have paid close attention to how these memories are made material through the analysis of commemorative culture in churches, for example, but perhaps not so much in Jewish tradition (eg Llewellyn 1996; Van Dyke and Alcock 2008; Schlunke 2013 inter alia). During the course of our work, 164 memorials were recorded at Sandys Row; each memorial was photographed and recorded using a pro-forma sheet. The entries were added to a schedule, and databased. We were particularly interested in asking a series of specific questions of this corpus of commemorative culture, viz.: (1) who was being commemorated (persons, events); (2) how were they being commemorative (form and material) and (3) where were they being commemorated in the space of the building. Such an analysis, which would be familiar to practitioners of medieval church archaeology in the UK (e.g. Williams 2003) and post-medieval church archaeology in the UK and North America (e.g. Llewellyn 2000), has the capacity to shed light on a great deal of social information, yet, as we have noted above, such an approach has not been attempted within the context of a working synagogue.

AQ7

Table 1 summarises the focus of the commemorative act within the male and female areas of the synagogue. The majority are named individuals, male, female or pairs (most often parents, rarely grandparents). In many cases the language used is very straightforward, the formula 'in loving memory of $X$ ' (the focus of the dedication) and the dedicatees, very often close collateral family members. In rare cases there is an additional line of Hebrew script, and a date, given in the western year and month with its Jewish equivalent. The commemoration of a Bar Mitzvah (a coming of age of age ritual when a boy at around 13 years becomes spiritually responsible for his own actions and eligible to be part of the Minyan, the quorum of 10 adult males required in Orthodox Tradition for public worship) is found in nine examples, and again the formula is straightforward: family with name of son and date. Some commemorative plaques give no indication of what is being commemorated, merely the name of the donors (this may relate to subscription to a burial society as only members of a synagogue who have paid for this service, were able to be buried in a Jewish cemetery). Multiple individuals (e.g. parents and perhaps a single sibling) are rarely encountered. 
Wedding anniversaries (two Ruby, two Golden and one Silver) make up another category of commemoration. A change of role (for example "election to the role of Chosen Torah and Chosen Berashi") is found in three examples. There is a single dedication to the Royal family (donated in memory of a named male individual, presumably of significant social or wealth standing in the community), a single birthday (seventieth celebrated by a couple in a single year) and one memorial to a soldier killed in action in World War Two, presented by his parents (Fig. 6, middle).

\section{Table 1}

Focus of commemorative culture at Sandys row synagogue, London

\begin{tabular}{|c|c|c|}
\hline Type & Number & Example inscription \\
\hline $\begin{array}{l}\text { Named } \\
\text { single male } \\
\text { individual }\end{array}$ & $\begin{array}{l}54(\mathrm{c} . \\
33 \%)\end{array}$ & $\begin{array}{l}\text { In loving memory of Reuben (Ruby) Cohen } \\
\text { Presented by his family (underlined) }\end{array}$ \\
\hline $\begin{array}{l}\text { Named } \\
\text { single female } \\
\text { individual }\end{array}$ & $\begin{array}{l}39(\mathrm{c} . \\
24 \%)\end{array}$ & $\begin{array}{l}\text { Presented in loving memory of Flora Lane (Lazarus) } \\
\text { By her husband \& sons (underlined) }\end{array}$ \\
\hline Parents & $\begin{array}{l}35(\mathrm{c} . \\
21 \%)\end{array}$ & $\begin{array}{l}\text { In loving memory of Rose \& Morris Simons } \\
\text { from Millie. Woolf \& Maurice Simons }\end{array}$ \\
\hline Bar Mitzvah & $9(\mathrm{c} .5 \%)$ & $\begin{array}{l}\text { Presented by Mr. \& Mrs. John Lane } \\
\text { To commemorate the Barmitzvah of their son } \\
\text { Jon Philip } \\
\text { 8th September } 1962 \text { 9th Ellul } 5722\end{array}$ \\
\hline None & $\begin{array}{l}8(\mathrm{c} . \\
5 \%)\end{array}$ & Presented by Mr. \& Mrs. M. Smith (underlined) \\
\hline $\begin{array}{l}\text { Multiple } \\
\text { individuals }\end{array}$ & $\begin{array}{l}5(\mathrm{c} . \\
3 \%)\end{array}$ & $\begin{array}{l}\text { Presented in loving memory of Avner \& Rifka Reinstein } \\
\text { and daughter Jane by their son and daughter-in-law Mr \& } \\
\text { Mrs Leonard L. Reinstein (underlined) }\end{array}$ \\
\hline $\begin{array}{l}\text { Wedding } \\
\text { anniversary }\end{array}$ & $\begin{array}{l}5(\mathrm{c} . \\
3 \%)\end{array}$ & $\begin{array}{l}\text { The candelabra presented by Mr \& Mrs S.N. Moscovitch \& } \\
\text { children } \\
\text { on the occasion of their golden wedding } \\
\text { On } 22 \text { nd October, } 1961(1911-1961)\end{array}$ \\
\hline $\begin{array}{l}\text { Change of } \\
\text { role }\end{array}$ & $\begin{array}{l}3(\mathrm{c} . \\
2 \%)\end{array}$ & $\begin{array}{l}\text { Presented by } \\
\text { Mr \& Mrs B. Miskin \& Mr \& Mrs M. Smith } \\
\text { on the occasion of their election to chosen Torah and } \\
\text { chosen Berashis (underlined) } \\
\text { 1963-5724 (Underlined) }\end{array}$ \\
\hline Grandparents & $\begin{array}{l}2(\mathrm{c} . \\
2 \%)\end{array}$ & $\begin{array}{l}\text { Presented by Graham Sulkin in loving memory of his } \\
\text { grandparents (underlined) }\end{array}$ \\
\hline Bat Mitzvah & $\begin{array}{l}1(\mathrm{c} . \\
0.5 \%)\end{array}$ & $\begin{array}{l}\text { In celebration of Sandys row's first Batmitzvah } \\
\text { Deborah Abraham } \\
\text { 19th October } 2002\end{array}$ \\
\hline
\end{tabular}




\begin{tabular}{|l|l|l|}
\hline \multicolumn{1}{|c|}{ Type } & Number & \multicolumn{1}{c|}{ Example inscription } \\
\hline $\begin{array}{l}\text { The } \\
\text { monarchy }\end{array}$ & $\begin{array}{l}1(\mathrm{c} . \\
0.5 \%)\end{array}$ & $\begin{array}{l}\text { Prayer for the queen and the royal family } \\
\text { Decorative line cf. Bauer Hall sign } \\
\text { Two lines of Hebrew text } \\
\text { Our sovereign lady Queen Elizabeth. } \\
\text { Elizabeth the queen mother. } \\
\text { Philip Duke of Edinburgh } \\
\text { Charles Prince of Wales and all the royal family } \\
\text { Six lines of Hebrew } \\
\text { Decorative curved line } \\
\text { Presented in loving memory of Harry Marks line of } \\
\text { Hebrew text by his wife and son }\end{array}$ \\
\hline $\begin{array}{l}\text { Killed in } \\
\text { action }\end{array}$ & $\begin{array}{l}1(\mathrm{c} . \\
0.5 \%)\end{array}$ & $\begin{array}{l}\text { Presented to Sandys row Ass. Synagogue by Mr \& Mrs J. } \\
\text { Lampert } \\
\text { In memory of our beloved son Jacob who was killed in } \\
\text { action in Burma } \\
\text { June 23rd 1944 Line of Hebrew text Corr. 2nd Tamuz 5704 }\end{array}$ \\
\hline Birthday & $\begin{array}{l}1(\mathrm{c} . \\
0.5 \%)\end{array}$ & $\begin{array}{l}\text { Presented by Mr and Mrs. M. Weller to commemorate their } \\
\text { 70th birthday (underlined) 1963 5724 }\end{array}$ \\
\hline
\end{tabular}

Fig. 6

Selection of memorial forms from Sandys Row: top, to right of Ark, menorah panel; middle war memorial; bottom selection of seat memorials. 


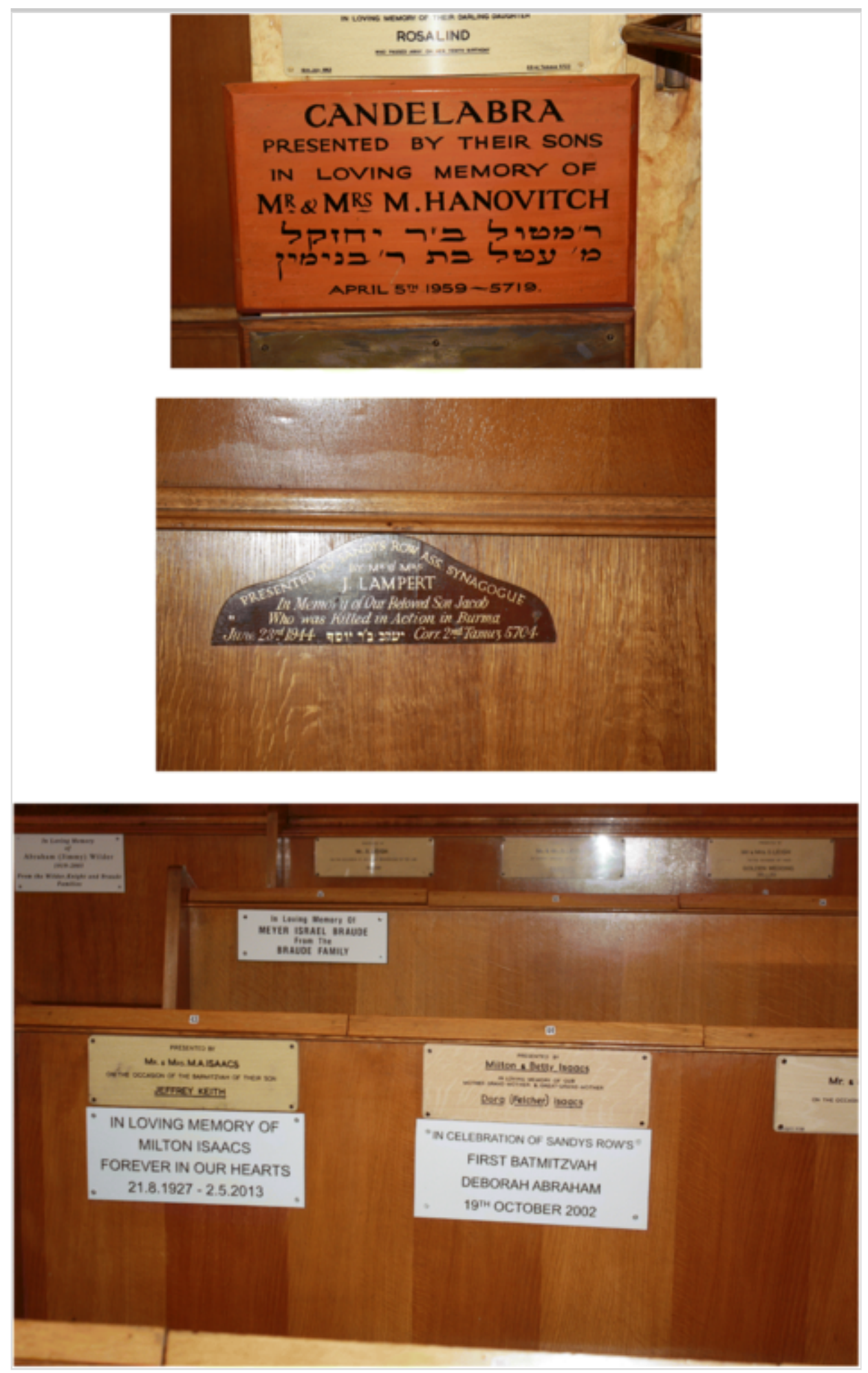

Table 2 summarises the material and positioning of each type of memorial. The vast majority (118 out of 164) take the form of simple plastic plaques on seats in both the male area below and the female gallery above. The older forms are light brown with plain lettering, the newer white with black lettering but the same font, suggesting perhaps the implication of equality in death. These bear a range of different dedications (mainly to name individuals, also events and changes of role). The single plaque to the soldier killed in action is noticeably different in using gold lettering (Commonwealth war graves, by way of comparison also 
indicate their differential status within a cemetery through the use of different material and typography). Two seats have double commemorations, suggesting a longer-lived family link. Wall-mounted candelabra, or menorahs, make up the next largest form of commemorative culture and are dedicated to the memories of individuals. These are found mainly along the walls of the synagogue, flanking the Ark and a single example in the porch. Miscellaneous forms of plaque, glass and a single clock make up the remainder of the memorials. The earliest plaque is found in the outer porch and commemorates the Treasurer Issac Levy, who died in May 1887; both selection of material as well as its positioning suggests the implication of the commemoration of an individual of high social standing in the community.

\section{Table 2}

material and positioning of memorial

\begin{tabular}{|c|c|c|}
\hline Form & Position & Remarks \\
\hline $\begin{array}{l}\text { Small plastic } \\
\text { seat plaques } \\
\text { (n. 118) }\end{array}$ & $\begin{array}{l}\text { Seats in top } \\
\text { gallery }(14) \\
\text { seats in lower } \\
\text { section }(114)\end{array}$ & $\begin{array}{l}\text { In two forms: a brown rectangular plastic plaque } \\
\text { and recent white plaques. }\end{array}$ \\
\hline $\begin{array}{l}\text { Wooden } \\
\text { plaque with } \\
\text { brass menorah } \\
\text { above (n. 20) }\end{array}$ & $\begin{array}{l}\text { In outer porch } \\
\text { (1); wall mounted } \\
\text { along top gallery } \\
\text { (7); wall mounted } \\
\text { along lower wall } \\
\text { (7); to right of } \\
\text { Ark (3) to left of } \\
\text { Ark (2) }\end{array}$ & $\begin{array}{l}\text { All commemorate named individuals. } \\
\text { Eg. Presented in loving memory of Mr and Mrs } \\
\text { J. Harris two lines of Hebrew by their children }\end{array}$ \\
\hline $\begin{array}{l}\text { Large marble } \\
\text { carved plaque } \\
\text { (n. 1) }\end{array}$ & In outer porch & $\begin{array}{l}\text { This tablet was erected by the wardens and } \\
\text { committee of the Sandy's row synagogue, in } \\
\text { grateful recognition of the unwearied and } \\
\text { eminent services rendered during a period of } \\
30 \text { years by their late treasurer (larger letters) } \\
\text { Isaac Levy, ESQr who departed this life } 8 \text { th Iyar } \\
5647-2 \text { nd May } 1887 \text { in his } 69 \text { the year (all in } \\
\text { capitals) }\end{array}$ \\
\hline $\begin{array}{l}\text { Large wooden } \\
\text { plaque (n.1) }\end{array}$ & Upper gallery & $\begin{array}{l}\text { Bauer Hall } \\
\text { (small decorative line) } \\
\text { This hall is dedicated to the memory of the late } \\
\text { Mr Lewis Bauer and has been made possible } \\
\text { through the genorosity of his widow Mrs Leah } \\
\text { Bauer \& the Bauer Family (small decorative } \\
\text { line) }\end{array}$ \\
\hline Clock (n. 1) & Upper gallery & Presented by Mr. and Mrs. J. Esterman \\
\hline $\begin{array}{l}\text { Stained Glass } \\
\text { (n.1) }\end{array}$ & $\begin{array}{l}\text { Lower wall, } \\
\text { north side. }\end{array}$ & $\begin{array}{l}\text { Presented by Mr J. M. Ischerowitz } \\
\text { a regular \& respected worshipper }\end{array}$ \\
\hline $\begin{array}{l}\text { Large wooden } \\
\text { plaque (n. 1) }\end{array}$ & Left of ark & Prayer to queen (see Table 1) \\
\hline
\end{tabular}




\begin{tabular}{|c|c|c|}
\hline Form & Position & Remarks \\
\hline $\begin{array}{l}\text { Red fabric } \\
\text { covering on } \\
\text { Bimah (n. 1) }\end{array}$ & Bimah & $\begin{array}{l}\text { In loving memory of Barnett Freedman } \\
\text { Line of Hebrew text } \\
\text { Presented by his family } \\
\text { 22nd Tebeth } 5726-4 \text { th Jan } 1966\end{array}$ \\
\hline $\begin{array}{l}\text { Scroll case (n. } \\
2)\end{array}$ & $\begin{array}{l}\text { Left and right of } \\
\text { ark bearing same } \\
\text { dedication }\end{array}$ & $\begin{array}{l}\text { Presented in Loving Memory of Solomon } \\
\text { Noorden } \\
\text { Left hand panel dates in Hebrew } \\
\text { Right hand panel 20th Dec } 1957 \text { 27th Kislev } \\
5718 \text { beneath scroll window } \\
\text { By his Wife and Children }\end{array}$ \\
\hline $\begin{array}{l}\text { Plaque with } \\
\text { curved top }\end{array}$ & Right of ark & $\begin{array}{l}\text { In memory of Nancy Brookarsh who passed } \\
\text { away } \\
\text { 6th Iyar 5715-28th April } 1955 \\
\text { Aged } 43 \text { years } \\
\text { Lines of Hebrew text below }\end{array}$ \\
\hline $\begin{array}{l}\text { Medium-sized } \\
\text { plastic } \\
\text { plaques }\end{array}$ & $\begin{array}{l}\text { on east-facing } \\
\text { wall of Bimah, } \\
\text { facing ark }\end{array}$ & $\begin{array}{l}\text { The lighting of the Almima (underlined) } \\
\text { presented in loving memory of Solomon } \\
\text { Engelsman } \\
\text { Executive officer 1935-1963 (underlined) } \\
\text { By his family (underlined) }\end{array}$ \\
\hline $\begin{array}{l}\text { Wooden } \\
\text { illuminated } \\
\text { sign }\end{array}$ & Left of ark & $\begin{array}{l}\text { In memory of Nancy Brookarsh who passed } \\
\text { away } \\
\text { 6th Iyar 5715-28th April } 1955 \\
\text { Aged } 43 \text { years }\end{array}$ \\
\hline $\begin{array}{l}\text { Large white } \\
\text { plastic plaque }\end{array}$ & Left of ark & $\begin{array}{l}\text { In loving memory of Phillip Green 1924-1985 } \\
\text { Bessie Green 1928-1990 } \\
\text { Missed by Sonny and Robert } \\
\text { Grandchildren Lucy, Gaby and Hannah }\end{array}$ \\
\hline Brass plaque & Left of ark & Five lines of Hebrew \\
\hline $\begin{array}{l}\text { Fabric curtain } \\
\text { with gold } \\
\text { device and } \\
\text { lettering/scroll } \\
\text { and floral } \\
\text { decoration }\end{array}$ & On ark & $\begin{array}{l}\text { Scroll/floral decoration presented by Mr. S Paule } \\
\text { In memory of his parents } \\
\text { Two lines of Hebrew }\end{array}$ \\
\hline
\end{tabular}

Chairs lend themselves to dedication. This motif is found in English churches, where dedications 'fix' family ownership of pews through the ages; in some cases, the 'selling' of pews and seats within church spaces allowed money to be raised to subsidise construction or more simply to buy the requisite number of chairs (eg Buggeln 2003: 50). Beyond the context of the ritual space, the memorial bench is a well-known feature of public spaces (Wylie 2009). At Sandys Row the chair dedications all date clearly from the 1950s to $1960 \mathrm{~s}$, suggesting that this was a measure taken to provide new seats for the renovated synagogue. There are no dedications from the 1970s, 1980s or 1990s, evidencing 
perhaps the decline of the community, and the sole dedication from the twentyfirst century celebrates an unusual event for an Orthodox congregation: the first Bat Mitzvah (the coming of age ceremony for a girl at around 12 years which marks her move into spiritual adulthood) to be held at the Synagogue.

Apart from the marble memorial to Isaac Levy, which is an earlier survival, the other commemorative forms (miscellaneous plaques, menorahs and ritual furniture) all suggest that the process of making memory material was explicitly linked to the provision by the donors of new furniture or decoration within the synagogue. The memorials themselves are very explicitly linked to family and lineage, and also by extension their function within the community too (although it is noted above that there is a large plaque to the left of the Ark which requests prayers for the Royal Family, evidencing the strong community identification with monarchy and country). In few cases the wording is formal, but on occasion a nickname (eg 'Jinny', 'Kitty', 'Mick') makes the memorial familiar, comforting and fixed within what was a small and gradually declining community at the time. The plaques also donate the seats held by that particular family, which would often be passed down from one generation to the other. There are still members of the congregation today at Sandys Row, including members of the Brookarsh and Freedman families, who can trace their family line back to founding Dutch members in the 1870s. They still retain the same seats within the Synagogue, evidencing a strong thread of social continuity. It is hoped at a later stage to map both the family names to their historic dwelling places in the area (using electoral rolls, census records and telephone directories) as well as similarly mapping the location of some of the Jewish businesses mentioned in promotional literature for synagogue fund raising events in the 1950s and 1960s.

The archaeology of commemoration and Sandys Row thus places a heavy emphasis upon the family, emphasising the centrality of community in the old Jewish East End, yet the temporal spread of them indicates a sadder aspect to this story: a picture of relative decline after the Second World War. Commemorative strategies focus very much upon homogeneity (emphasising equality in death) with a few exceptions; motivation for commemoration also appears to link to the need to refurbish the renovated synagogue, as well as marking the memory of individuals. From the ritual space above, we now move to the basement (the future heritage centre) and a consideration of a quite different category of material evidence.

\section{Hoarding and the Holy: Material Culture from the Synagogue Basement}


We will all be familiar with the behavioral notion of hoarding, the inability not to discard material straight away but perhaps to quarantine it in an intermediate space (shed, attic) owing to the immediate emotional response of jettisoning it, or thinking that the object might yet have some utility (still yet to be revealed; Frost and Gross 1993). The basement area at Sandys Row is a perfect archaeological example of this form of behavior, yet the notion of the archaeology of the hoarder takes on quite a different light when faced with very distinctive demands of Jewish ritual behavior and discard of material culture 'in the right way;' in the spiritually and ritually approved manner.

The basement had been scheduled for clearance in 2017 prior to conversion to a heritage centre focusing on the role of the synagogue in the Jewish East End. This was an opportunity to try to apply an 'archaeological' approach to categorizing the material before it was removed - and in some cases discarded. All material was photographed and recorded, and broad analysis of the material in the basement shows that much of it reflects ritual use for the synagogue (as would be expected) but also as an educational establishment as well as a space with business and commercial links too. Special attention attaches to a large iron decorated chest (dated, according to specialists from the Victoria and Albert Museum to the mid seventeenth century). The chest, which features a substantial locking device, contains a wooden platform with 8 holes drilled into it. It is highly likely this chest contained rimmonim, finials (frequently made of silver) used to decorate the Sefer Torah as small silver and gold bells were found in the bottom of the chest when it was opened. Frequently shaped to resemble pomegranates (other shapes include bells and crowns as noted here), which were believed to contain 613 seed, rimmonim symbolized the 613 commandments (Mitzvot) in the Torah. The chest is an unusual find within the context of a synagogue basement (Fig. 7).

\section{Fig. 7}

Iron chest from the basement Sandys row synagogue. Scale length $50 \mathrm{~cm}$ 


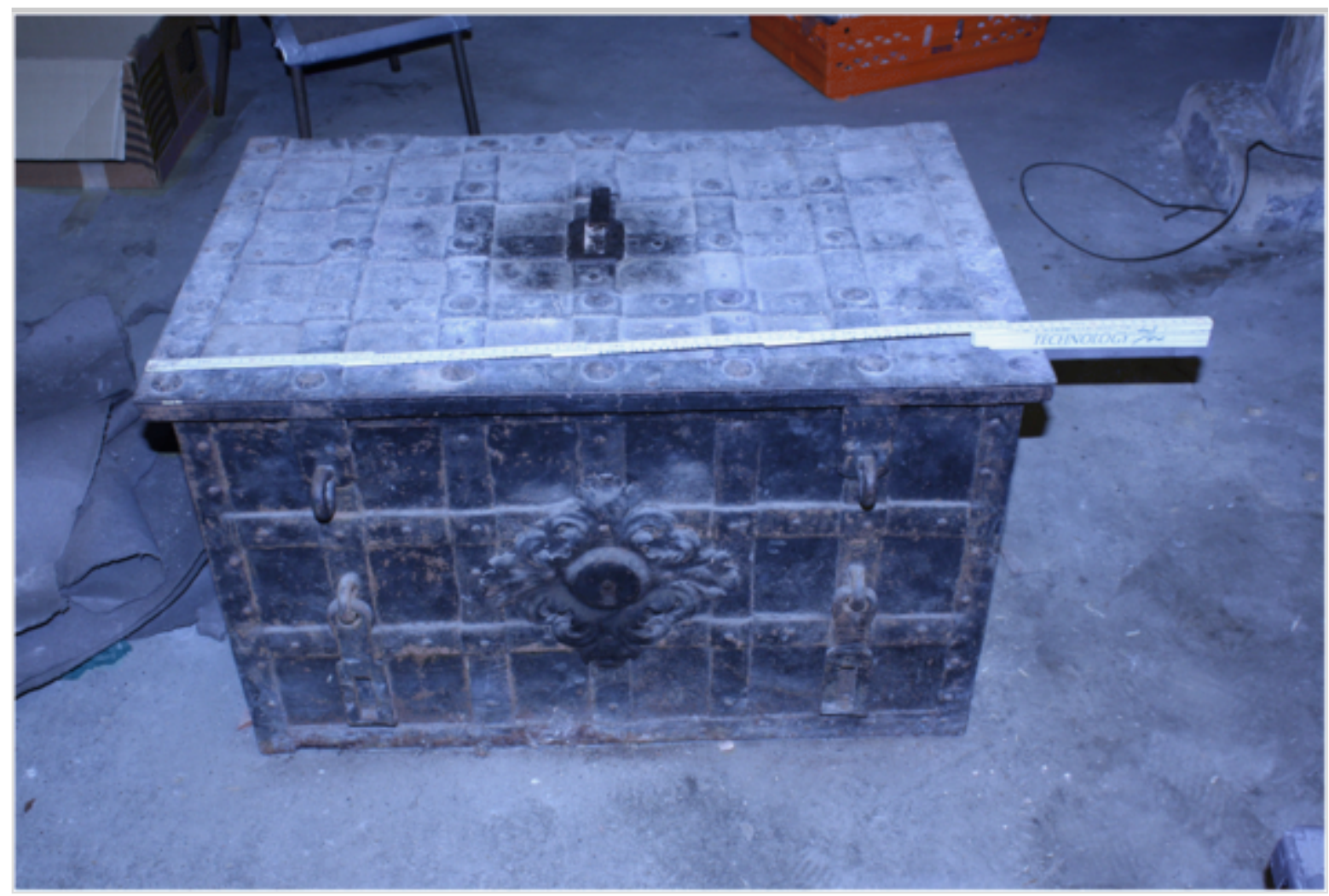

A large number of handwritten minute books, documents and archives had already been moved to the nearby Bishopsgate Institute for conservation and archiving, but a large amount of printed material remained in the basement. For the most part these were didactic materials (such as Hebrew language books), subscription forms, correspondence and publications relating to fundraising events. Subscription forms to the Women's Holy Vestment Society add a corrective to the sense of a male dominated material culture. Furnishings, and material associated with commerce, such as calculating machines, typewriters and a trolley from nearby Spitalfields or Petticoat Lane markets, were also recorded and photographed, and evidence the site's use as a centre for the local traders' association. This material is all indicative of the multi-functional role that the synagogue played within the local economy and society.

There was also a great deal of material culture associated with daily ritual life of the synagogue community in the Basement. It is important to note, however, that this was not material that had been casually discarded, but was awaiting disposal in the correct ritual manner (e.g. through burial in a Jewish graveyard; Greene 1992). Such items included old worn prayer books, and the prayer shawls (tallit) and teffilin, small leather boxes containing rolls of hand-lettered parchment inscribed with verses (Exodus 13:1-10, 11-16 and Deuteronomy 6:4-9, 11:31$21)$, worn by male Jews during prayers in accordance with the Biblical commandments (Exodus 13:9 and 13:16 and Deuteronomy 6:8 and 11:18); they 
are also known by the Greek term phylactery meaning 'protection'; Fig. 8. Material culture associated with the female members of the synagogue was also present in the basement. Of particular note are the statements and ledger books from the Ladies Society for Providing Holy Vestments, as well as a collection of Holy Vestments.

Fig. 8

Teffilin with embroidered bag, basement of Sandys row

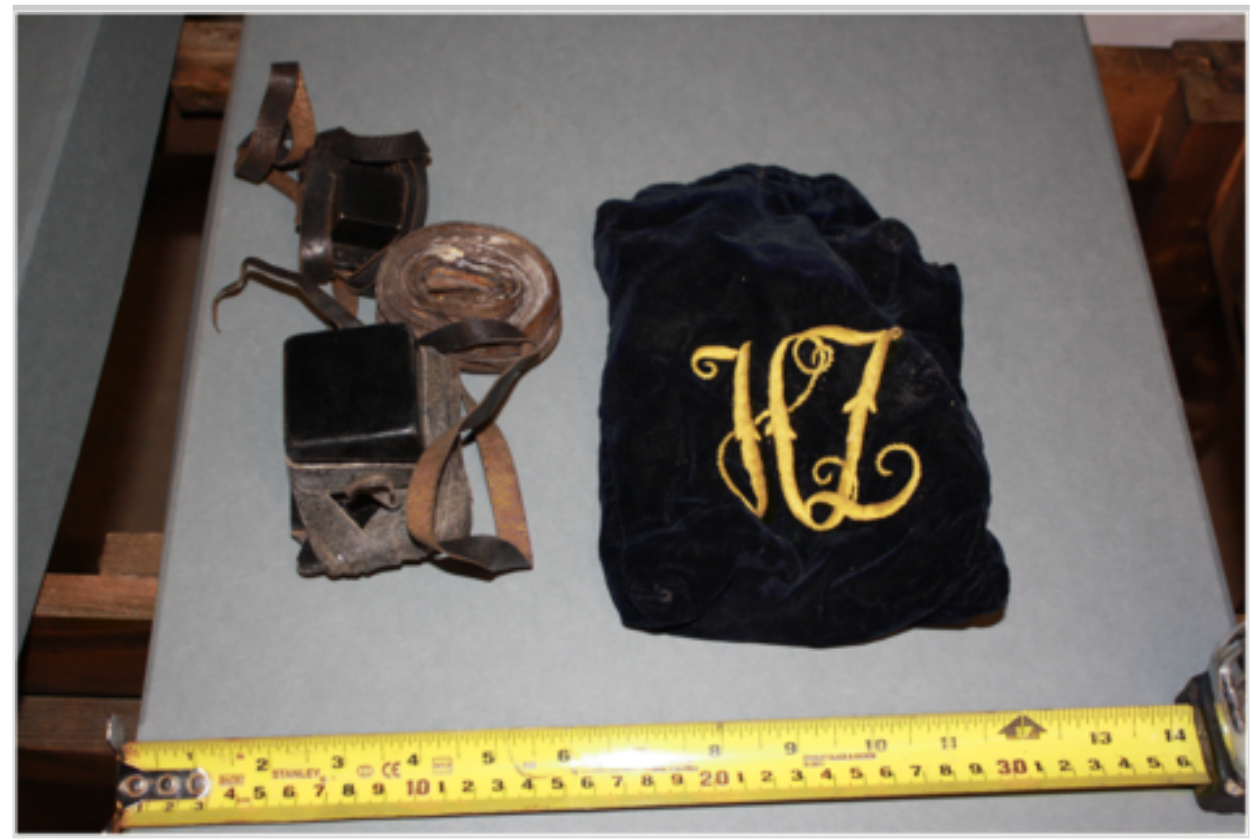

The provision of Holy Vestments (notably decorated mantles for the Sefer Torah) and parochets (curtains for the Torah Ark) gave, and continues to give, traditional Orthodox Jewish women an intimate connection with the most sacred text, the Sefer Torah. Reminiscent of the robes worn by the High Priest in the Temple, the provision of Torah mantles accords with the Babylonian Talmudic injunction (Shabbat, 113b) regarding the commandment of adornment (hiddur mikveh). This relates to Exodus 15:2 and the requirement to beautify and adorn items connected with G-d and the name of G-d, as a form of piety (Schachar 1975: 1). The Mantles (Holy Vestments) were made form a variety of materials. A few were made of second-hand materials, with one fashioned from the material that covered the seats of a train. Most however, were made from brocade and velvet, and embroidered with gold thread and silver panels in a variety of designs. Torah Mantles, Tefillin bags, mezuzah cases, and printed or handwritten synagogue documents are considered in Judaism as accessories to holiness (tashmishey kedusha), although they are less potent in terms of sacrality than Sefer Torah, tefillin (both the cases and the text), and mezuzah klaf which have a specially sanctified status (Greene 1992). 
The material held in the basement at Sandys Row therefore reflects two very different forms of behavior in relation to the discard process, firstly the curating of secular objects (that reflect the broad use of the building by both genders) and secondly 'delayed disposal' of tashmishey kedusha while awaiting proper religious disposal (Greene 1992: 31). The material culture is also important for shedding light on wider issues in social history. Printed documents and personal letters, for example, have also helped inform our programme of wider memory mapping of the old Jewish East End, often giving the names and locations of long-disappeared Jewish family businesses.

\section{Conclusion: Sandys Row in Microcosm and Macrocosm}

"By then there was little left of the Jewish East End: crumbling buildings, derelict sites, rapidly fading signs. 'This used to be----now it is a car park'....' If you look really hard you can just make out the mark of a mezuzah here"”

(Lichtenstein and Sinclair 2000: 37).

Our work at Sandys Row synagogue has allowed us to take a very archaeological perspective on the material biography of a Jewish ritual building, and has furnished a new view on the material traces of changing ritual space, commemorative behavior and the approaches to the ritual disposal of sacred objects. For one of the present authors (RL) the notion of using an archaeological approach to accessing a rich and multilayered history of the Jewish East End is already well established (see Shanks 2004); Lichtenstein's 'excavation' of the memory of one individual, David Rodinsky was undertaken in his room as well as in oral history research (Lichtenstein and Sinclair 2000). Our research has demonstrated the possibilities of using archaeological methodologies to frame the Jewish habitus of the east end of London, its religious, social, cultural and economic framework, in the same manner as other scholars have sought to disentangle notions of identity and material culture (cf Jefferies 2001). Sandys Row synagogue started out as the ritual home for a minority within a minority, and over the years its appearance and associated material culture mirrors the wider fortunes of the Ashkenazi community of the Old Jewish East End.

On the wider scale comes the recognition that this is also a distinctive heritage at risk, and has to be managed and interpreted for future generations (cf Kadish 
2002). The new heritage centre at Sandys Row will play a part in helping pin these ghosts of the old Jewish East End in place, making its psychogeography real to a new generation of tourists and urban explorers (Pinder 2001). The 'Our Hidden Histories' oral history project that focused on the old Jewish community of Sandys Row (undertaken by RL) has shown the value of imaginative, integrated and multi-disciplinary approaches to unraveling the complex picture of religious and ethnic identity in large city spaces over the last 100 years or so (cf Gard'ner 2004). This In turn will lead to a more detailed programme of memory mapping, as we combine oral history testimony with GIS-based mapping of old East End Jewish sites on the ground, and make this information available through a range of accessible digital media. AQ8

Perhaps more provocatively, our study at Sandys Row, when contextualized within the wider cityscape, allows us to perceive perhaps a very different picture of the organization of Jewish space in the old Jewish East End than is popularly thought. The writer Iain Sinclair, for example, draws our attention to the way that the influential British Jewish social historian Raphael Samuel (1934-1996) viewed Spitalfields: "like Emanuel Litvinoff, he interpreted the area round Brick Lane in terms of the ghetto, he linked it with settlements in Poland and Russia, never with Islington, Hackney or Southwark" (Lichtenstein and Sinclair 2000: 175). For Samuel, he saw "Spitalfields as a shtetl (an eastern European Jewish village) of the last days" (Lichtenstein and Sinclair 2000: 177), meaning rather than an integrated and cosmopolitan microcosm as any other London suburb (as Kershen 2004 noted, see above), we are seeing a Jewish community, layered upon the city scape, and not inhabiting within it. Samuel's very 'bottom up' approach to heritage and social history (e.g. Samuel 2012) focuses upon the immediate family inhabiting and interacting within its neighbourhood rather than the top down metanarrative. The material culture of Sandys Row synagogue, and its place within a wider framework of Jewish places in the old East End, very much echoes this concept of a superimposition of identity upon, rather than embedded within, the cityscape of East London.

\section{Acknowledgements}

The authors wish to record their gratitude to the Sandys Row community, in particular Mr. Harvey Rifkind, the current president of Sandys Row. Jonathan Wells has provided a huge amount of assistance with the project, in archives and in the Synagogue itself. A small team of University of Winchester students assisted in the recording process; supervised by Dominic Roberts they included: Tom Brown, Louise Clare, Hermione Noyce and Zoe Umpleby. The comments of 
two anonymous referees were gratefully received and have improved the original paper immeasurably. Any errors remain the fault of the authors.

\section{References}

\section{AQ9}

Ackroyd, P. (1995). Dan Leno and the Limehouse Golem. Vintage Press, London.

Alexander, C. (2011). Making Bengali brick Lane: Claiming and contesting space in East London. The British Journal of Sociology 62(2): 201-220.

Banton, M. (1955). The Coloured Quarter. Negro Immigrants in an English City. Jonathan Cape, London.

Brotmanblog (2014). Brotmanblog: a family journey. My ancestor was a Chut: more on English and Dutch Jews. Available online at:

https://brotmanblog.com/2014/05/08/my-ancestor-was-a-chut-more-on-dutchand-english-jews/, accessed 29th Sept 2017.

Buggeln, G. (2003). Temples of Grace: The Material Transformation of Connecticut's Churches 1790-1840. University Press of New England, Hannover.

El-Solh, C. (2010). Somalis in London's east end: A community striving for recognition. Journal of Ethnic and Migration Studies 4: 539-552.

Frost, R., and Gross, R. (1993). The hoarding of possessions. Behaviour Research and Therapy 31(4): 367-381.

Gard'ner, J. (2004). Heritage protection and social inclusion: A case study from the Bangladeshi Community of East London. International Journal of Heritage Studies 10(1): 75-92.

Glasman, J. (1987). London synagogues in the late nineteenth century: Design in context. The London Journal 13(2): 143-155.

Green, J. (1991). A Social History of the Jewish East End in London, 19141939: A Study of Life, Labour and Liturgy. E. Mellen Press, Lampeter. 
Greene, V. (1992). "Accessories of holiness": Defining Jewish sacred objects. Journal of the American Institute for Conservation 31(1): 31-39.

Hachilli, R. (1998). Ancient Jewish Art and Archaeology in the Diaspora. Brill, Leiden.

Hachlili, R. (2001). The Archaeology of Judaism. In Insoll, T. ed., Archaeology and World Religion. Routledge, London, pp. 96-122.

Hall, M. (2006). Identity, memory and Countermemory: The archaeology of an urban landscape. Journal of Material Culture 11(1-2): 189-209.

Hicks, D., and Horning, A. (2006). Historical Archaeology and Buildings. In Hicks, D., Beaudry, M. eds., The Cambridge Companion to Historical Archaeology. Cambridge University Press, Cambridge, pp. 273-292.

Hinton, D. (2003). Medieval Anglo-Jewry: The Archaeological Evidence. In Skinner, P. ed., The Jews in Medieval Britain: Historical, Literary and Archaeological Perspectives. Boydell, Woodbridge, pp. 97-111.

Isserlin, R. (1996). Building Jerusalem in The 'islands of the sea': The Archaeology of Medieval Anglo-Jewry. In Kadish, S. ed., Building Jerusalem: Jewish Architecture in Britain. Valentine-Mitchell, London, pp. 34-53.

Jacobus, A. (1998). Ashkenazi Dutch in Spitalfields in Whitechapel mid nineteenth century. Unpublished report available online at: https://web.archive.org/web/20061011060836/http://www.zen28027.zen.co.uk/dutc , accessed 25th march 2018.

Jefferies, N. (2001). Historically visible but archaeologically invisible? The Huguenots in seventeenth century Spitalfields. Medieval Ceramics 25: 54-64.

Kadish, S. (1991). Squandered heritage: Jewish buildings in Britain. Immigrants and Minorities: Historical Studies in Ethnicity, Migration And Diaspora 10(1/2): 147-165.

Kadish, S. (2002). Constructing identity: Anglo-Jewry and synagogue architecture. Architectural History 25: 386-408.

Kadish, S. (2004). The 'cathedral synagogues' of England. Jewish Historical Studies 39: 45-77. 
Kadish, S. (2006). Jewish Heritage in England: An Architectural Guide. English Heritage Publications, London.

Kershen, A. (2004). The construction of home in a Spitalfields landscape. Landscape Research 29(3): 261-275.

Kershen, A. (2005). Strangers, Aliens and Asians: Huguenots, Jews and Bangladeshis in Spitalfields 1660-2000. Routledge, Abingdon.

Kershen, A., and Vaughan, L. (2013). "There was a priest, a rabbi and an imam...": An analysis of urban space and religious practice in London's east end, 1685-2010. Material Religion 9(1): 10-35.

Kushner, T. (1991). The end of the 'Anglo-Jewish progress show':

Representations of the Jewish east end, 1887-1987. Immigrants and Minorities: Historical Issues in Ethnicity. Migration and Diaspora 10(1-2): 78-105.

Lichtenstein, R. (2007). On Brick Lane. Hamish Hamilton, London.

Lichtenstein, R., and Sinclair, I. (2000). Rodinsky's Room. Granta, London.

Llewellyn, N. (1996). Honour in life, death and in the memory: Funeral monuments in early modern England. Transactions of the Royal Historical Society 6: 179-200.

Llewellyn, N. (2000). Funeral Monuments in Post-Reformation England. Cambridge University Press, Cambridge.

Marks, K. (2012). The Archaeology of Anglo-Jewry 1656-1880. Archaeopress, Oxford.

Marriot, J. (2011). Beyond the Tower: A History of East London. Yale University Press, New Haven.

Mavrommatis, G. (2010). A racial archaeology of space: A journey through the political imaginings of Brixton and brick Lane, London. Journal of Ethnic and Migration Studies 36(4): 561-579.

Mytum, H. (2006). Popular attitudes to memory, the body, and social identity: The rise of external commemoration in Britain, Ireland and New England. 
Post-Medieval Archaeology 40(1): 96-110.

Nanzeen, A., Garnett, J., Gidley, B., Harris, A., and Keith, M. (2016). Shifting markers of identity in East London's diasporic religious spaces. Ethnic and Racial Studies 39(2): 223-243.

Newman, D. (1985). Integration and ethnic spatial concentration: The changing distribution of the Anglo-Jewish community. Transactions of the Institute of British Geographers 10(3): 260-376.

O’Neill, G. (1999). My East End: A History of Cockney London. Viking, London.

Palmer, A. (2000). The East End: Four Centuries of London Life. Faber, London.

Parker, G. (2009). Huguenot identity in post-medieval London. Assemblage 10: $7-15$.

Parker, G. (2011). Expressions of Conformity: Identifying Huguenot Religious Beliefs in the Landscape. In King, C., Sayers, D. eds., The Archaeology of Post-Medieval Religion. Boydell, Woodbridge, pp. 107-122.

Pinder, D. (2001). Ghostly footsteps: Voices, memories and walks in the city. Ecumene 8(1): 1-19.

Roemer, N. (2009). London and the east end as spectacles of urban tourism. Jewish Quarterly Review 99(3): 416-434.

Roth, C. (1950). The Great Synagogue 1690-1940. Publisher E. Goldston, London.

Rubens, K. (2001). Bevis marks synagogue and the City churches. Jewish Historical Studies 37: 117-131.

Samuel, R. ed. (2012). Theatres of Memory: past and present in contemporary culture. Verso Publishers, London.

Sandysrow.org.uk (2017) History. Available online at: http://sandysrow.org.uk/\#history-section, accessed 29 Sept 2017 
Schachar, I. (1975). The Jewish Year; iconography of religions XXIII, 3. Leiden, Brill.

Schlunke, K. (2013). Memory and materiality. Memory Studies 6(3): 253261.

Seed, J. (2006). Limehouse blues: Looking for Chinatown in the London docks, 1900-1940. History Workshop Journal 62(1): 58-85.

Shanks, M. (2004). Three rooms: Archaeology and performance. Journal of Social Archaeology 4(2): 147-180.

Sinclair, I. (2017). The Last London: True Fictions from an Unreal City. One World, London.

Smith, R. (1981). The London Jews' Society and patterns of Jewish conversion in England, 1801-1859. Jewish Social Studies 43(3/4): 275-290.

Spicer, A. (2002). 'Qui est de Dieu dit la parole de Dieu': the Huguenots and their temples. In Mentzer, R., Spicer, A. eds., Society and culture in the Huguenot World. Cambridge University Press, Cambridge, pp. 1559-1685.

Stell, C. (2002). An Inventory of NonConformist Chapels and Meeting Houses in Eastern England. English Heritage Publications, London.

Van Dyke, R., and Alcock, S. eds. (2008). Archaeologies of Memory. John Wiley \& Sons, Oxford.

Vaughan, L. (1994). The Jews in London 1695 and 1895. Unpublished MSc thesis, The Bartlett Graduate School/University College London.

Vaughan, L., Sailer K. and Dino, B. (2016). The built fabric of the east endExploring the socio-spatial configuration if nineteenth century religious sites and spaces. Unpublished paper presented at the Urban History Group 2016: re-evaluating the place of the city in history, Robinson College, University of Cambridge, 31 march 2016-1 ${ }^{\text {st }}$ April 2016.

Waterman, S., and Kosmin, B. (1986). The distribution of Jews in the United Kingdom. Geography 71(1): 60-64. 
Whipple, A. (2009). Revisiting the "rivers of blood" controversy: Letters to Enoch Powell. Journal of British Studies 48(3): 717-735.

Williams, B. (1991). Heritage and community: The rescue of Manchester's Jewish past. Immigrants and Minorities: Historical Studies in Ethnicity, Migration and Diaspora 10(1/2): 128-146.

Williams, H. (2003). Remembering and Forgetting the Medieval Dead. In Williams, H. ed., Archaeologies of Remembrance: Death and Memory in Past Societies. Springer, New York, pp. 227-254.

Wylie, J. (2009). Landscape, absence and the geographies of love.

Transactions of the Institute of British Geographers 34(3): 275-289. 